\title{
Analysis of the germination proteins in Alicyclobacillus acidoterrestris spores subjected to external factors
}

\author{
Izabela Porębska ${ }^{\llbracket}$ and Barbara Sokołowska ${ }^{1,2}$ \\ 1 Prof. Wacław Dąbrowski Institute of Agricultural and Food Biotechnology, Department of Fruit and Vegetable Technology, Warsaw, Poland: \\ 2Institute of High Pressure Physics of the Polish Academy of Sciences, Laboratory of Biomaterials, Warsaw, Poland
}

\begin{abstract}
The presence of Alicyclobacillus acidoterrestris, a thermoacidophilic and spore-forming bacterium, in pasteurized acidic juices poses a serious problem for the processing industry. Therefore, the use of other more effective techniques, such as high hydrostatic pressure (HHP) and supercritical carbon dioxide (SCCD), is considered for preserving juices in order to inactivate these bacteria, while reducing the loss of nutrients and sensory quality of juices. On the other hand, HHP and SCCD when combined with a moderately elevated temperature can induce germination of bacterial spores, making them more vulnerable to inactivation. The spore germination can be also induced by nutrients, such as L-alanine or a mixture of asparagine, glucose, fructose and potassium ions (AGFK). The aim of this work was to determine whether applying activating agents: HHP, SCCD and nutrient germinants (L-alanine and the AGFK mixture), could influence the number of spores which start to germinate and how this affects the proteins involved in the spore germination. SDS-PAGE was used to resolve proteins isolated from the $A$. acidoterrestris spores. The results that were obtained indicate that the germination of $A$. acidoterrestris spores treated with HHP, SCCD and nutrient germinants reflect the number of spores which start to germinate. The SDS-PAGE data indicated changes in the level of selected proteins occurring when subjected to the germination activating factors as well as noticeable differences in those proteins' molecular weights.
\end{abstract}

Key words: Alicyclobacillus acidoterrestris, spore germination, germination proteins, SDS-PAGE

Received: 19 August, 2016; revised: 04 October, 2016; accepted: 17 October, 2016; available on-line: 21 April, 2017

e-mail: porebska@ibprs.pl

Abbreviations: A. acidoterrestri, Alicyclobacillus acidoterrestri; AGFK, asparagine, glucose, fructose and potassium ions mixture; DPA, dipicolinic acid; HHP, high hydrostatic pressure; SCCD, supercritical carbon dioxide

\section{INTRODUCTION}

Alicyclobacillus acidoterrestris is a Gram-positive, sporeforming and thermoacidophilic bacterium which survives a typical pasteurization process, causing spoilage of juices by producing compounds associated with a disinfectantlike odour: guaiacol, 2,6-dibromophenol, 2,6-dichlorophenol and 2,6-dibromophenol (Orr et al., 2000).

The spores of $A$. acidoterrestris are extremely resistant to a variety of environmental stresses. The structure and chemical composition of the spores differs considerably from those of vegetative cells because of the multilayer structure surrounding the spore core, which consists of the exosporium, spore coat, outer membrane, cortex and cell germ wall, and the inner membrane. The spore core contains the DNA, RNA, ribosomes and most of the enzymes. The core also contains high levels of a small molecule, the dipicolinic acid (DPA), which exists as a 1:1 chelate with divalent cations, predominantly $\mathrm{Ca}^{2+}$. Such structure largely accounts for the unique spore resistance to the environmental stress (Setlow et al., 2014b; Bassi et al., 2016).

Conditions within the core are strongly linked to the spore's resistance properties which are involved in protecting the spore's DNA from damage. There are two principal methods of minimizing the effect of DNA damage to the spore: firstly, by preventing the DNA damage to occur, and secondly by ensuring the detoxification and repair of any DNA damage during spore germination. Small acid-soluble proteins (SASP), which are found exclusively in spores, are synthesized late into sporulation and only in the developing spore, and are degraded early during germination, providing a vital source of free amino acids for the outgrowing spore. They contain a large percentage of hydrophobic amino acids and bind directly to and saturate the spore DNA, therefore providing an important component of spore resistance against external treatment which targets spore DNA from many types of damage (Moeller et al., 2014).

The spores of $A$. acidoterrestris have the ability to survive under typical conditions used for pasteurization, which also enables them to germinate and grow. Therefore, the use of other more effective techniques such as high hydrostatic pressure (HHP) and supercritical carbon dioxide (SCCD) are considered for preserving juices in order to inactivate these bacteria, while reducing the loss of nutrients and sensory quality of the juices. To enhance the effectiveness of the process, it is recommended that germination be induced and the spores transformed into a more susceptible vegetative form. The data indicate that in the case of $A$. acidoterrestris, HHP (Porębska et al., 2015a; 2015b; Sokołowska et al., 2015; Vercammen et al., 2012) as well as SCCD (Porębska et al., 2016a; 2016b), combined with a moderately elevated temperature, may be a useful technique for both, the germination and inactivation of $A$. acidoterrestris spores in apple juice and buffers. The germination of $A$. acidoterrestris spores can be also induced by various nutrients: amino acids, purine nucleosides, sugars (Lovdal et al., 2012), L-alanine (Paredes-Sabja et al., 2011; Kuwana et al., 2013; Cruz-Mora et al., 2015), ions and combinations of these, and a mixture of asparagine, glucose, fructose and potassium ions (AGFK) (Gosh et al., 2012; Stewart et al., 2012).

Spore germination of Bacillus species (Setlow 2014a) and Clostridium species (Paredes-Sabja et al., 2014; Francis 
et al., 2015) is an excellent model system to study the molecular mechanisms underlying the pressure and nutritional control of growth and development. The binding of specific chemical nutrients to spore cognate receptors (GRs) located in the inner membrane triggers the germination process that leads to resumption of metabolism in spore outgrowth. A major signal that triggers spore germination is the presence of specific nutrients called germinants in the spore's environment. These nutrient germinants are typically amino acids, purine nucleosides or sugars which are recognized in a stereospecific manner by GRs.

The spores of $A$. acidoterrestris have characteristic properties and consist of complex structures including various types of proteins. The spore germination mechanism could be triggered by L-alanine, which acts through the GerA receptor, or a mixture of L-asparagine, fructose, glucose and potassium (AGFK) through the GerB and GerK receptors (Paredes-Sabja et al., 2011; Paidhungat et al., 2002). However, high hydrostatic pressure promoted germination at $100-400 \mathrm{MPa}$ and also triggered germination through the GerA, GerB and GerK receptors, but a higher pressure, up to $600 \mathrm{MPa}$, retarded this process (Setlow et al., 2003a; Paidhungat et al., 2002; Paredes-Sabja et al., 2011; Nguyen Thi Minh et al., 2010; Luu et al., 2015).

As noted above, in addition to nutrients, spores can be germinated by using HHP of 100 to $800 \mathrm{MPa}$. At an HHP of 100 to $300 \mathrm{MPa}$, germination is caused by GR activation. However an HHP of 500-800 MPa, causes germination by the release of the Ca-DPA depot from the spores and may act on specific Ca-DPA channels in the inner membrane of the spore (Koong et al., 2014; Setlow, 2014b; Sarker et al., 2015; Wang et al., 2015; Porębska et al., 2015b).

The exposure of spores to relatively low HHP levels $(100-400 \mathrm{MPa})$ and moderate temperatures $\left(20-75^{\circ} \mathrm{C}\right)$ stimulated spore germination and triggered the GRs of $B$. subtilis during the germination of individual spores. Under moderate pressure, the individual GRs displayed differing levels of sensitivity to pressure (Setlow et al., 2003B, Zhang et al., 2014).

The aim of this work was to determine whether applying activating agents: HHP, SCCD and nutrient germinants (L-alanine and AGFK mixture) could influence the number of spores which start to germinate and how this affects the proteins involved in the spore germination.

\section{MATERIALS AND METHODS}

Tested organism. The $A$. acidoterrestris strains TO$169 / 06$ and TO-117/02 used in this work were isolated from a Polish concentrated apple juice, using the International Federation of Fruit Juice Producers' method (2004/2007). These strains were chosen from among eight wild strains tested previously (Skapska et al., 2012). TO-117/02 was a strain highly resistant to temperature, HHP and SCCD and TO-169/06 was a more sensitive one (Porębska et al., 2015a; 2015b; 2016a; 2016b).

Spore production. Spores were produced based on the method described by Sokołowska and coworkera (2012) and were suspended in apple juice $\left(11.2^{\circ} \mathrm{Bx}, \mathrm{pH}\right.$ 3.4) or in a McIlvain buffer solution of $\mathrm{pH} 4.0$ and $\mathrm{pH}$ 7.0 , at approximately $6 \log \mathrm{cfu} / \mathrm{mL}$.

High hydrostatic pressure treatment. Samples of A. acidoterrestris spores were subjected to high pressure at the Institute of High Pressure Physics, The Polish Acad- emy of Science, using the U 4000/65 (Unipress) apparatus. The volume of the treatment chamber was 0.95 $\mathrm{L}$ and the maximum pressure $600 \mathrm{MPa}$. The pressuretransmitting fluid used was distilled water and polypropylene glycol (1:1). A pressure of up to $500 \mathrm{MPa}$ was generated in 70-80 s; the release time was 2-4 s. The pressurization times reported do not include the comeup and come-down times.

Thirteen milliliter samples, in polyethylene tubes (Sarstedt), were exposed to HHP treatment at $300 \mathrm{MPa}$ and a temperature of $50^{\circ} \mathrm{C}$ for $15 \mathrm{~min}$. The highest germination of $A$. acidoterrestris spores and release of DPA were achieved using these process parameters in previous studies (Porębska et al., 2015b). The assays were performed using two independent samples. Unpressurized samples were used as controls. After treatment, the samples were removed from the chamber and placed immediately on ice. They were then stored at $4^{\circ} \mathrm{C}$ until further analysis.

Supercritical carbon dioxide treatment. Samples of $A$. acidoterrestris spores were subjected to supercritical carbon dioxide using Applied Separations Spe-ed SFE supercritical fluid extraction apparatus. The volume of the treatment chamber was $10 \mathrm{~mL}$, the maximum pressure $69 \mathrm{MPa}$, and the maximum temperature $120^{\circ} \mathrm{C}$. Seven milliliter samples were exposed in glass tubes to supercritical $\mathrm{CO}_{2}$ at $60 \mathrm{MPa}, 75^{\circ} \mathrm{C}$ for $30 \mathrm{~min}$. The highest germination of $A$. acidoterrestris spores and release of DPA were achieved in previous studies by using these process parameters (Porębska et al., 2016b). After processing, the samples were stored at $4^{\circ} \mathrm{C}$ until further analysis. The assay was performed with two independent samples. Unprocessed samples were used as controls.

Treatment with nutrient germinants. L-alanine (50 $\mathrm{mM})$ or AGFK mixture $(50 \mathrm{mM})$ were added to the spore suspension samples which were afterwards subjected to a temperature of $80^{\circ} \mathrm{C} / 10 \mathrm{~min}$ and incubated at $45^{\circ} \mathrm{C}$ (Bevilacqua et al., 2014), up until the moment of a significant decrease in OD, indicating germination of the spores (Porębska et al., 2015a; 2016a).

Preparation of samples for SDS-PAGE. After exposure to the activating factors, the $A$. acidoterrestris spore suspension at approximately $6 \mathrm{log} \mathrm{cfu} / \mathrm{mL}$ was centrifuged at $17000 \times \mathrm{g}$ for $10 \mathrm{~min}$ at $4^{\circ} \mathrm{C}$. The spores were washed once with $10 \mathrm{mM}$ sodium phosphate buffer $(\mathrm{pH}$ 7.2). To remove cellular debris and vegetative cells, the pellets were suspended in $0.1 \mathrm{ml}$ of a lysozyme buffer (10 mM sodium phosphate, $\mathrm{pH} 7.2 ; 1 \%$ lysozyme; complete protease inhibitor tablets from Roche) and incubated at room temperature for $10 \mathrm{~min}$. The pellets were then washed repeatedly with a buffer $(10 \mathrm{mM}$ sodium phosphate, $\mathrm{pH} 7.2 ; 0.5 \mathrm{M} \mathrm{NaCl})$ at room temperature and then incubated with SDS and 2-mercaptoethanol to extract all germination proteins. The samples were stored at $-20^{\circ} \mathrm{C}$ prior to analysis (Kuwana et al., 2002; Takamatsu et al., 2000; Lai et al., 2003; Sreshty et al., 2011, Thompson et al., 2011).

SDS-PAGE electrophoresis. Sodium dodecyl sulphate polyacrylamide gel electrophoresis (SDS-PAGE) was carried out with a Bio-Rad Mini PROTEAN ${ }^{\circledR}$ Tetra Cell electrophoresis system. SDS-PAGE was conducted to determine the number and size of the proteins of the germinated spores after being subjected to external factors.

Spore proteins were solubilized in $0.1 \mathrm{ml}$ loading buffer (Tris-HCl, pH 6.8; 4\% SDS; 10\% 2-mercaptoethanol; $10 \%$ glycerol; $0.05 \%$ bromo-phenol blue) and boiled for 5 min. The proteins were separated on 14\% SDS-PAGE and visualized by using Coomassie brilliant blue R-250 
dyes. The stained gel was washed in 10\% acetic acid and then analyzed (Takamatsu et al., 2000). Each sample was examined three times.

\section{RESULTS AND DISCUSSION}

The results obtained in our previous studies, which examined, among other things, the influence of the temperature, time and pressure of HHP and SCCD treatments and incubation with L-alanine and AGFK mixture, on the degree of inactivation and germination of the $A$. acidoterrestris spores by using optical density methods (Porębska et al., 2015a; 2016a; 2016c), and the DPA release during pressure-induced germination of $A$. acidoterrestris spores (Porębska et al., 2015b; 2016b), enabled selection of the optimal temperature and pressure conditions for research in this work. In this work, we wanted to show changes in the level of proteins during spore germination of two strains of $A$. acidoterrestris: TO$117 / 02$ and TO-169/06, when subjected to certain external factors.

\section{Lanes 1-3 before SCCD processing, lanes 4-7 after SCCD processing}

The results of the analysis of the changes in the level of proteins before and after treatment with the activating agents are shown in Figs $1-5$. Proteins isolated from the $A$. acidoterrestris spores were tested using SDS-PAGE, and the profiles obtained were compared with the protein marker before and after being subjected to the external factors.

In order to estimate the levels of proteins released from the germinated A. acidoterrestris 169/06 spores, SDS-PAGE was used, where such proteins may be visualized with Coomassie blue staining and with some percussion showed their molecular mass, before and after SCCD treatment at $60 \mathrm{MPa}, 75^{\circ} \mathrm{C}$ (Fig. 1).

\section{Lanes 1-4 after HHP processing, lanes 7-8 before the} HHP processing, lanes 5-6 were left empty

The levels of proteins released from the germinated A. acidoterrestris TO-117/02 spores, before and after HHP treatment at $300 \mathrm{MPa}, 75^{\circ} \mathrm{C}$ are shown in Fig. 2.

\section{Lanes 1-4 after HHP processing, lanes 5-6 before HHP processing}

In order to estimate the levels of proteins released from the germinated $A$. acidoterrestris 169/06 spores, they

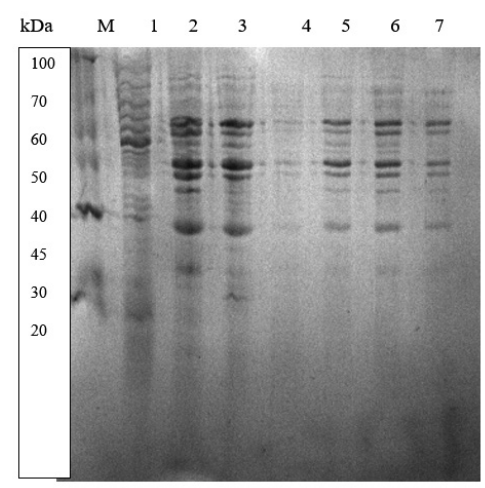

Figure 1. The levels of proteins involved in the spore germination of Alicyclobacillus acidoterrestris 169/06 (lanes 2-3 and 5-7) and 117/02 (lanes 1 and 4) after SCCD at $60 \mathrm{MPa}, 75^{\circ} \mathrm{C}$. were visualized using Comassie blue-stained SDS-PAGE before and after $\mathrm{HHP}$ treatment at $300 \mathrm{MPa}, 75^{\circ} \mathrm{C}$ (Fig. 3).

\section{Lanes 1-3 after incubation with L-alanine, lanes 4-6 before incubation with L-alanine}

Figure 4 displays the levels of proteins involved in the germination of spores of $A$. acidoterrestris 169/06 before and after incubation with L-alanine.

\section{Lanes 1-6 after incubation with the AGFK mixture, lanes 7-9 before incubation with the AGFK mixture}

The levels of proteins in the total lysates of $A$. acidoterrestris TO-169/06 spores (lanes 4-6 and 8-9) and TO$117 / 02$ (lanes 1-3 and 7) involved in the germination, before and after incubation with the AGFK mixture are shown in Fig. 5.

Comparing the lanes with samples taken before and after the action of activating factors, it is clear that a significant amount of proteins was released from the germinated treated spores, whereas no significant amount of proteins was released from the untreated, ungerminated spores.

Lower levels of proteins were observed in the case of $A$. acidoterrestris TO-117/02, indicating a weaker germination process. This phenomenon, and the difference between treated and untreated spores and differentiation between the strains was also observed by Setlow and coworkers (2015).

The levels of the proteins found in the germinated spores of $A$. acidoterrestris subjected to the external fac-

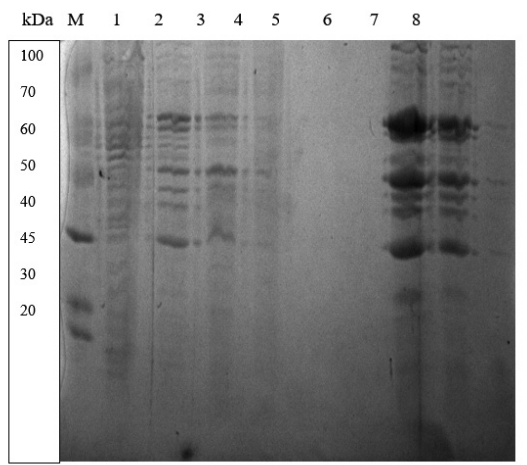

Figure 2. The levels of proteins involved in the germination of spores of Alicyclobacillus acidoterrestris $117 / 02$ after HHP at 300 $\mathrm{MPa}, 75^{\circ} \mathrm{C}$.

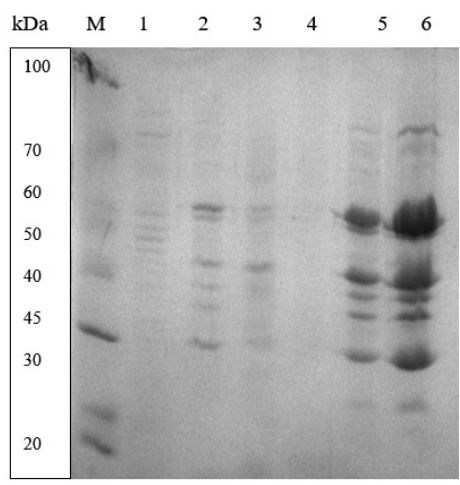

Figure 3. The levels of proteins involved in the germination of spores of Alicyclobacillus acidoterrestris $169 / 06$ after HHP at 300 $\mathrm{MPa}, 75^{\circ} \mathrm{C}$ 


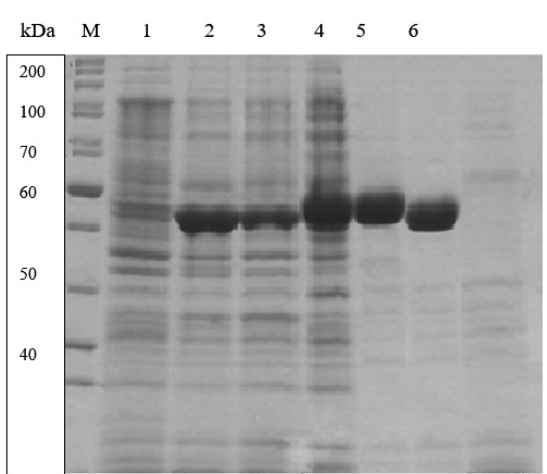

Figure 4. The levels of proteins involved in the germination of spores of Alicyclobacillus acidoterrestris 169/06 after incubation with L-alanine.

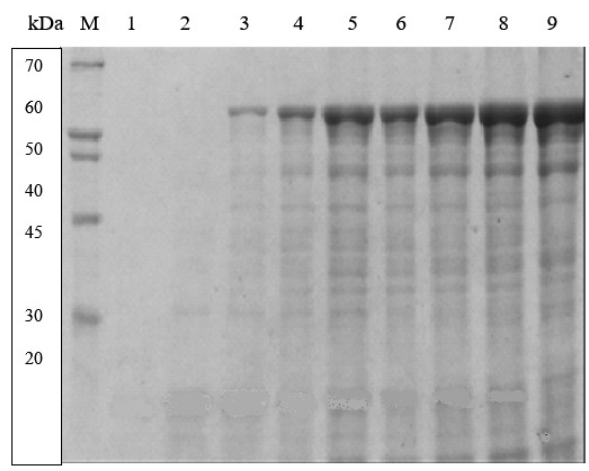

Figure 5. The levels of proteins in the total lysates of spores of Alicyclobacillus acidoterrestris TO-169/06 (lanes 4-6 and 8-9) and TO-117/02 (lanes 1-3 and 7) before and after incubation with the AGFK mixture.

tors are rather stable because there is no synthesis and degradation. The proteins which are involved in germination are not necessarily released from the spore, as for example the germination receptors. This proves that their level may change in the course of germination only in the direction of lowering their amount.

These results may be a prelude to expanding our current knowledge about the complex multifactorial process of sporulation and spore germination, and could help in analysis of a wider mechanism of gene expression involved in these processes in the future.

Changes in the protein level may be related to the existence of a number of mechanisms that govern the germination of spores. Bacterial spores contain unique highand low-molecular-mass proteins. Some of these proteins contribute directly or indirectly to the unique characteristics of the spores, such as dormancy, a high degree of resistance and, in particular, a unique cell morphology. Therefore, a comprehensive analysis of the protein composition would provide useful basic information and facilitate our understanding of the germination process at the molecular level (Setlow 2014a; 2014b). Protein sequencing would be required in subsequent experiments to exactly determine the type of proteins involved in the germination process.

The changes in the levels of proteins in germinated spores are related to the DPA release by the GR-independent germinants (Bevilacqua et al., 2015; Wang et al., 2015; Porębska et al., 2015b; 2016b; 2016c) which was also confirmed when monitoring spore germination by measuring optical density at an early stage of spore germination (Porębska et al., 2015a).
The developments in new technologies, combined with advances in understanding the mechanisms of bacterial spore resistance and germination, justify the need to summarize the current knowledge of these molecular mechanisms to help identify novel strategies to inactivate bacterial spores using innovative technology (Troiano et al., 2015; Stewart \& Setlow, 2013). Meanwhile, our knowledge on the mechanism of $A$. acidoterrestris germination is still very vague and limited. Selecting a group of proteins involved in the germination process of $A$. acidoterrestris spores by determining their level before and after exposure to an activating agent is important for understanding this complex phenomenon.

Until now, no studies have been reported on the analysis of germination proteins of $A$. acidoterrestris spores subjected to HHP, SCCD and nutrient germinants.

\section{CONCLUSION}

The results obtained in this study indicate that germination of $A$. acidoterrestris spores subjected to $\mathrm{HHP}$ and SCCD for different time periods and to nutrient germinants, reflect the number of spores which start to germinate and thus the proteins are more accessible for extraction, but overall the amount of proteins in the spore remains the same, independent of the way of breaking the dormancy state. Moreover, these results indicate that the external factors' influence level the amount of released proteins by the spores, visualized by SDS-PAGE gels.

The results obtained indicate that changes in the germination process of spores are visible at molecular level and that the level of proteins from untreated ungerminated spores was smaller than the amount of proteins which was released from the treated, germinated spores. These results may be a prelude to expanding our current knowledge about the complex multifactorial processes of sporulation and spore germination, and in the future help in analysis of the mechanism regulating gene expression involved in these processes.

\section{REFERENCES}

Bassi D, Colla F, Gazzola S, Puglisi E, Delledonne M, Sandro P, Cocconcelli PS (2016) Transcriptome analysis of Bacillus thuringiensis spore life, germination and cell outgrowth in a vegetable-based food model. Food Microbiol 55: 73-75. http://dx.doi.org/10.1016/j. fm.2015.11.006

Bevilacqua A, Ciuffreda E, Sinigaglia M, Corbo MR (2014) Effects of lysozyme on Alicyclobacillus acidoterrestris under laboratory conditions. Int J Food Sci Technol 49: 224-229. doi: 10.1111/ijfs.12302

Bevilacqua A, Ciufureda E, Sinigaglia M, Rosario Corbo M (2015) Spore inactivation and DPA release in Alicyclobacillus acidoterrestris under stress conditions. Food Microbiol 46: 299-306. doi: 10.1016/j. fm.2014.08.017

Cruz-Mora J, Pérez-Valdespino A, Gupta S, Withange N, Kuwana R, Takamatsu H, Christie G, Setlow P (2015) The GerW protein is not involved in the germination of spores of Bacillus species. PLoS One 10. doi: 10.1371/journal.pone.0119125.

Francis MB, Allen ChA, Sorg JA (2015) Spore cortex hydrolysis precedes dipicolinic acid during Clostridium difficile spore germination. $J$ Bacteriol 197: 2276-2283. doi:10.1128/JB.02575-1

Kuwana R, Kasahara Y, Fujibayashi M, Takamatsu H, Ogasawara N, Watabe K (2002) Proteomics characterization of novel spore proteins of Bacillus subtilis. Microbiol 148: 3971-3982. doi: 10.1099/00221287-148-12-3971

Lai E-M, Phadke ND, Kachman MT, Giorno R, Vazquez S, Vazquez JA, Maddock JR, Drinks A (2003) Proteomic analysis of the spore coats of Bacillus subtilis and Bacillus anthracis. I Bacteriol 185: 14431454. doi: 10.1128/JB.185.4.1443-1454.2003

Lovdal IS, From C, Madslien EH, Romundset KC, Klufterud E, Rosnes JT, Granum PE (2012) Role of the gerA operon in L-alanine germination of Bacillus lichenoformis spores. BMC Microbiol. 12: 34. doi:10.1186/1471-2180-12-34 
Luu S, Cruz-Mora J, Setlow B, Feeherry FE, Doona CJ, Setlow P (2015) The effects of heat activation on Bacillus spore germination, with nutrients or under pressure, with or without various germination proteins. Appl Env Microbiol 81: 2927-2938. doi: 10.1128/ AEM.00193-15

Moeller R, Raguse M, Reitz G, Okayasu O, Li Z, Klein S, Setlow P, Nicholson WL (2014) Resistance of Bacillus subtilis spore DNA to lethal ionizing radiation damage relies primarily on spore core components and DNA repair, with minor effect of oxygen radical detoxification. Appl Env Microbiol 80: 104-109. doi: 10.1128/ AEM.03136-13

Nguyen Thi Minh H, Dantigny P, Perrier-Cornet JM, Gervais P (2010) Germination and inactivation of Bacillus subtilis spores induced by moderate hydrostatic pressure. Biotechnol Bioeng 107: 876-883. doi: 10.1002/bit.22849

Orr RV, Shewfelt R L, Huang CJ, Tefera S, Beuchat LR (2000) Detection of guaiacol produced by Alicyclobacillus acidoterrestris in apple juice by sensory and chromatographic analyses, and comparison with spore and vegetative cell populations. J Food Protect 63: 15171522. doi: http://dx.doi.org/10.4315/0362-028X-63.11.1517

Paidhungat M, Setlow B, Daniels W B, Hoover D, Papafragkou E, Setlow P (2002) Mechanisms of induction of germination of Bacillus subtilis spores by high pressure. Appl Environ Microbiol 68: 3172 3175. doi: 10.1128/AEM.68.6.3172-3175.2002

Paredes-Sabja D, Setlow P, Sarker MR (2011) Germination of spores of Bacillus and Clostridiales species: mechanisms and proteins involved. Trends Microbiol 19: 85-94. doi: 10.1016/j.tim.2010.10.004

Paredes-Sabja D, Shen A, Sorg JA (2014) Clostridium difficile spore biology: sporulation, germination, and spore structural proteins. Trend Microbiol 22: 406-416. doi: 10.1016/j.tim.2014.04.003

Porębska I, Rutkowska M, Sokołowska B (2015a) Decrease in optical density as a results of germination of Alicyclobacillus acidoterrestris spores under high hydrostatic pressure. High Press Res 35: 89-97. http:/ /dx.doi.org/10.1080/08957959.2015.1006630

Porębska I, Sokołowska B, Woźniak L, Skąska S, Fonberg-Broczek M, Rzoska SJ (2015b) DPA release and germination of Alicyclobacillus acidoterrestris under HHP. J Nutr Food Sci 5: 6. http://dx.doi. org/10.4172/2155-9600.1000438

Porębska I, Sokołowska B, Laniewska-Trokenheim L (2016a) Effect of supercritical carbon dioxide on inactivation and germination of Alicyclobacillus acidoterrestris spores. Żywność Nauka Technol 1: 67-76 (in Polish). doi: 10.15193/zntj/2016/104/110

Porębska I, Sokołowska B, Woźniak Ł, Łaniewska-Trokenheim $~$ L (2016b) The dipicolinic acid release and germination of Alicyclobacillus acidoterrestris spores under SCCD. Pol J Natur Sci 31: 681-691

Porębska I, Sokołowska B, Woźniak \& (2016c) Dipicolinic acid release and the germination of Alicyclobacillus acidoterrestris spores under nutrient germinants. Pol J Microbiol 1: 57-64. doi: 10.5604/17331331.1234994

Sarker MR, Akhtar S, Torres JA, Paredes-Sabja D (2015) High hydrostatic pressure-induced inactivation of bacterial spores. Crit Rev Microbiol 41: 18-26. http://dx.doi.org/10.3109/1040841X.2013.78847

Setlow P (2003a) Spore germination. Curr Opin Biotechnol 6: 556. http:// doi.org/10.1016/j.mib.2003.10.001

Setlow B, Cowan AE, Setlow P (2003b) Germination of spores of Bacillus subtilis with dodecylamine. J Appl Microbiol 95: 637-648. doi: 10.1046/j.1365-2672.2003.02015

Setlow P (2014a) Germination of spores of Bacillus Speciec: What we know and do not know. J Bacteriol 196: 1297-1305. doi: 10.1128/ JB.01455-1
Setlow P (2014b) Spore resistance properties. Microbiol Spectrum 2: TBS0003-2012. doi: 10.1128/microbioispec.TBS-0003-2012

Setlow B, Korza G, Blatt KMS, Fey JP, Setlow P (2015) Mechanism of Bacilus subtilis spore inactivation by and resistance to supercritical $\mathrm{CO}_{2}$ plus peracetic acid. I Appl Microbiol 120: 57-69. doi: 10.1111/ jam.12995

Skapska S, Sokołowska B, Dekowska A, Chotkiewicz M, Fonberg-Broczek M (2012) Application of high pressure pasteurization to inactivate spores of Alicyclobacillus acidoterrestris in apple juice. Żywność Nauka Technol Jakość 3: 187-196 (in Polish). doi: 10.15193/ zntj/2012/82/187-196

Sokołowska B, Skapska S, Fonberg-Broczek M, Niezgoda J, Chotkiewicz M, Dekowska A, Rzoska SJ (2012) The combined effect of high pressure and nisin or lysosyme on the inactivation Alicyclobacillus acidoterrestris spores in apple juice. High Pressure Res 32: 119-127. doi: 10.1080/08957959.2012.664642

Sokołowska B, Skąpska S, Fonberg-Broczek M, Niezgoda J, Porębska I, Dekowska A, Rzoska SJ (2015) Germination and inactivation of Alicyclobacillus acidoterrestris spores induced by moderate hydrostatic pressure. Pol J Microbiol 64: 351-359. doi: 10.5604/17331331.117029

Sreshty MA, Misra S, Murty UNS (2011) Interpreting the SDS-PAGE protein patterns with self-organizing maps: application for the characterization of mosquito-pathogenic Bacillus strains. J Appl Microbiol 110: 239-247. doi: 10.1111/j.1365-2672.2010.0488

Stewart KA, Yi X, Ghosh S, Setlow P (2012) Germination protein levels and rates of germination of spores of Bacillus subtilis with overexpressed or deleted genes encoding germination proteins. J Bacteriol 194: 3156-3164. doi: 10.1128/JB.00405-12

Stewart KAV, Setlow P (2013) Numbers if individual nutrient germinant receptors and other germination proteins in spores of Bacillus subtilis. J Bacterial 198: 3575-3582. doi:10.1128/JB.00377-13

Takamatsu H, Kodama T, Imamura A, Asia K, Kobayashi K, Nakayama T, Ogasawara N, Watabe K (2000) The Bacillus subtilis yabG gene in transcribed by SigK RNA polymerase during sporulation and $y a b G$ mutant spores have altered coat protein composition. I Bacteriol 182: 1883-1888. doi:10.1128/JB.182.7.1883-1888.2000

Thompson BM, Binkley JM, Stewart GC (2011) Current physical and SDS extraction methods do not efficiently exosporium protiens from Bacillus anthracis spores. J Microbiol Methods 85: 443-148. doi: 10.1016/j.mimet.2011.02.009

Troiano A, Zhang J, Cowan Ae, Setlow P (2015) Analysis of the dynamics of a Bacillus subtilis spore germination protein complex during spore germination and outgrowth. J Bacteriol 197: 252-261. doi: 10.1128/JB.02274-14

Vercammen A, Vivijs B, Lurquin I, Michiels CW (2012) Germination and inactivation of Bacillus coagulans and Alicyclobacillus acidoterrestris spores by high hydrostatic pressure treatment in buffer and tomato sauce. Int J Food Microbiol 152: 162-167. doi: 10.1016/j.ijfoodmicro.2011.02.019

Wang S, Setlow P, Li Y (2015) Slow leakage of Ca-dipicolinic acid from individual Bacillus spores during initiation of spore germination. J Bacteriol 197: 1095-1103. doi: 10.1128/JB.02490-1

Zhang P, Liang J, Yi X, Setlow P, Li Y (2014) Monitoring of commitment, blocking and continuation of nutrient germinations of individual Bacillus subtilis spores. I Bacteriol 196: 2443-2454. doi: 10.1128/JB.01687-14 